Research Report

\title{
Preventing Dental Cavities with Mouth Rinsing Song for Elementary School Students, Sawahan District, Surabaya City
}

\author{
Yohana Vita Melodi Hutapea, Intan Andiyani, Fanny Nuradiyah, Ica Yusticia, Agung Ridwan Hidayanto, Anggi \\ Pramita, Vivin Dwi Fadila, Indi Mazaya Syarifah, Rizki Amelia Fatah, Muhammad Halim, Dwi Susanti and \\ Agung Sosiawan \\ Departement Dental Public Health, \\ Faculty of Dental Medicine, Universitas Airlangga \\ Surabaya - Indonesia
}

\begin{abstract}
Background: Dental and oral health is one of the public health indicators. Dental and oral health problems decrease individual health function. A lack of mouth rinsing causes dental and oral health problems in children after consuming sweet food. Dental health promotion can help the children learn about mouth rinsing and encourage them to have it regularly. MisDent is an educational program about dental health designed for children. We demonstrated and promoted mouth rinsing to the students, especially after they confused sweet food. Purpose: To promote correct tooth brushing to children and help monitoring student's dental health partnering with the local public health center. Methods: The program used dental health promotion strategies Patemon 2 Elementary School. We evaluated the program as well. Results: About 60\% of students at Petemon 2 Elementary School were able to answer the questions correctly, have mouth rinsing correctly, memorize the "REK KUMUR REK" song. Conclusion: "MisDent" involved the first and second-grade students of Patemon 2 Elementary School. The program was expected to help to educate the students about dental and oral health.
\end{abstract}

Keywords: dental and oral health; mouth rinsing; behavior; health education.

Correspondence: Agung Sosiawan. Department of Dental Public Health, Faculty of Dental Medicine, Universitas Airlangga, J1. Prof. Dr. Moestopo 47 Surabaya 60132 - Indonesia. Email: agung-s@fkg.unair.ac.id

\section{INTRODUCTION}

Dental and oral hygiene affects the quality of life, including the function of speech, mastication, and self-confidence. Organic deposits such as pellicles, alba material, food scraps, and dental plaque is an indicator of dental hygiene. A large amount of plaque on the teeth surface indicates poor dental hygiene. Plaque plays an important role in causing dental and oral health problems. The accumulation of plaque in the oral cavity will cause inflammation to the soft and supporting tissues due to the presence of microorganisms.

Soft drinks are becoming more popular with various flavors. Worldwide Food (2014) reported that soft drinks consumption in Indonesia increased by $48.57 \%$ annually. Indonesia is the fifth largest country that consumes soft drinks instead of mineral water, and carbonated water is the most popular soft drink. Soft drinks are most often consumed by adolescents aged 15-20 years old. Soft drinks and isotonic drinks are popular because they are widely available on the market and have various flavors.
Consumers generally do not aware of the effect of soft drinks and isotonic drinks on the oral cavity. ${ }^{1}$ Consumers usually drink soft drinks or isotonic drinks slowly, allowing sugar to accumulate in the tooth surface. This will affect dental health.

Also, energy drinks are popular among adults. This was in line with the fact that dental caries prevalence in adults is increasing. Dental caries is a progressive disease caused by accumulated food debris and glucose. Some drinks are made from fermented carbohydrates, and they can cause plaque accumulation and cause dental caries. ${ }^{2}$ Some soft drinks cause tooth erosion, plaque accumulation, and promote dental caries because they have low $\mathrm{pH}$ and high carbohydrates. ${ }^{3}$ Soft drinks generally contain sweeteners, acids, and natural and artificial flavorings. Carbonated and isotonic drinks are non-alcoholic baverages. ${ }^{4}$ Soft drinks and isotonic drinks have almost the same acidity and sweet flavors. Soft drinks have several effects on the oral cavity. Research shows that the $\mathrm{pH}$ of soft drinks is between 2.4-4.5. However, the critical $\mathrm{pH}$ is 5.5. This means that soft 
drinks promote demineralization of tooth enamel because they have $\mathrm{pH}$ below the critical $\mathrm{pH}$ limit. $^{5}$

Foods and drinks high in carbohydrates such as sucrose are easily accumulated to the surface of the teeth. The accumulated plaque will then cause dental caries. ${ }^{5}$ Therefore, soft drink consumption is linked to accumulate plaque, which then causes dental caries. Each soft drink has a different sucrose level. This means that different soft drinks would contribute to the plaque accumulation differently as well. Our PKL team concerned about this, and we were motivated to address the issue by creating an educational movie called MisDent. The movie promotes mouth rinsing in children, especially after they consume high sugar intake.

\section{MATERIALS AND METHODS}

The program used dental health promotion strategies in Patemon 2 Elementary School. We evaluated the program as well. The program took place in the morning before the class started. The MisDent (Dental Mistery) program was held simultaneously with the One Week One Brush program. While the first graders were learning about dental health and practicing tooth brushing, the second graders were watching MisDent movie. The MisDent program was started with in-class dental health promotion by 4 professional students, followed by watching MisDent movie, singing "REK KUMUR REK" ("LET RINSE OUR MOUTH”), quizzes, and educational game about mouth rinsing. After that, each class took turns heading to the field to rinse their mouths together.

The MisDent movie could motivate the students about mouth rinsing because it was evaluated using a summative method. The evaluation was carried out at the end of the program to examine how far they have progressed. The postest result showed that $60 \%$ of the students had answered the questions correctly.

\section{RESULTS}

After the students learned about mouth rinsing and causes of dental caries, an evaluation was carried out. The result showed that $60 \%$ of the students had answered the questions correctly, learned how to mouth rinse correctly, and memorized the "REK KUMUR REK" song.

\section{DISCUSSION}

The health promotion and prevention program is an effort to improve the degree of public health. Various methods and techniques are used in conveying information related to health. At present, methods of delivering health information use a variety of media, both visual, verbal, and interaction are widely used to increase effectiveness. This method is more favored by the audience, because it can improve the ability to receive information by involving many senses. ${ }^{6}$
People will be easier and happy to receive information that contains a lot of pictures, sounds, and even animations. This can improve the ability to receive information through visual presentations. ${ }^{7,8}$ In this empowerment program, video media is used to deliver health messages.

The SWOT analysis of the program: (1) Strength: The health promotion materials about mouth rinsing was delivered through a short movie. We also added a catchy song to help the first and second graders memorize the information. (2) Weakness: It requires engaging yet useful film footage and requires bigger funding due to the lack of human resources in video editing. (3) Opportunity: Potentially became routine dental health care behavior from the school to accustom them with mouth rinsing, especially after consuming high sugar food or drink. (4)Threat: Sugary food consumption in children cannot be controlled and unsupportive environment.

The MisDent program took place on 8 March 2018 at Patemon 2 Elementary School involving the first and second graders. This program was implemented under the Sawahan Public Health Center coverage area. The program was started by watching MisDent movie, narrating the consequence of poor dental hygiene, in this case, reluctance to have mouth rinsing, to dental health. The team was then lead the student to sing the "Rek Kumur Rek" song. At the end of the program, the team explained and emphasized the importance of mouth rinsing after eating. The students were then encouraged to continue practicing mouth rinsing at home to habituate them.

In a study conducted by Dahodwala in 2018, stated that $61 \%$ of respondents gave a positive response to health education with video media. ${ }^{9}$ Video media with moving images, is considered more effective, because in addition to displaying images, also accompanied by narration that tells the condition of the image. This can attract the attention of the audience and the ease of recalling information that has been obtained. ${ }^{10}$ In the research also found that the implementation of the image can affect the response of the audience to health instructions, and improve their health behavior. ${ }^{10-12}$

\section{CONCLUSION}

MisDent involved the first and second-grade students of Patemon 2 Elementary School. The program was expected to help to educate the students about dental and oral health.

\section{REFERENCES}

1. Coombes JS. Sports drinks and dental. Am J Dent. 2005;18(2):101-4.

2. Edwina KA., Sally J. Dasar-dasar Karies Penyakit dan Penanggulangannya. Jakarta: EGC; 1991. 218 p.

3. Bamise C, Kolawol K, Oloyede E. The determinants and control of soft drinks-incited dental erosion. Rev clín pesq odontol. 2009;5(2):141-54. 
Indonesian Journal of Dental Medicine Volume 2 Issue 1 2019; 19-21

4. Prasetyo EA. Keasaman minuman ringan menurunkan kekerasan permukaan gigi (Acidity of soft drink decrease the surface hardness of tooth). Dent J (Majalah Kedokt Gigi). 2005;38(2):60.

5. Patel H, Wagner M, Singhal P, Kothari S. Systematic review of the incidence and prevalence of genital warts. BMC Infect Dis. 2013 Jan 25;13(1):39.

6. Stein C, Santos NML, Hilgert JB, Hugo FN. Effectiveness of oral health education on oral hygiene and dental caries in schoolchildren: Systematic review and meta-analysis. Community Dent Oral Epidemiol. 2018 Feb 1;46(1):30-7.

7. Alhayek AA, Alsulaiman M, Almuhanna H, Alsalem M, Althaqib M, Alyousef A, et al. The effect of conventional oral health education versus animation on the perception of Saudi males in primary school children. J Int Oral Heal. 2018 May 1;10(3):121.

8. Berniyanti T, Kandar H, Bramantoro T, Wening GS, Palupi R, Kusumo A. Educational banner as a media to oral health during pregnancy phase information for pregnant women with lower secondary social economy. J Int Oral Heal. 2019 Jan 1;11(7):10.

9. Dahodwala M, Geransar R, Babion J, de Grood J, Sargious P. The impact of the use of video-based educational interventions on patient outcomes in hospital settings: A scoping review. Patient Educ Couns. 2018 Dec 1;101(12):2116-24.

10. Houts PS, Doak CC, Doak LG, Loscalzo MJ. The role of pictures in improving health communication: A review of research on attention, comprehension, recall, and adherence. Vol. 61, Patient Education and Counseling. Elsevier Ireland Ltd; 2006. p. 173-90.

11. Delp C, Jones J. Communicating information to patients: The use of cartoon illustrations to improve comprehension of instructions. Acad Emerg Med. 1996;3(3):264-70.

12. Katz MG, Kripalani S, Weiss BD. Use of pictorial aids in medication instructions: A review of the literature. Am J Heal Pharm. 2006;63(23):2391-7. 